\title{
The Role of Communication in Mount Kelud Eruption Disaster Management Program (Case Study in Ngantru Village, Ngantang District, Malang)
}

\author{
Jedda Ayu Inggrida ${ }^{*}$, Keppi Sukesi ${ }^{2}$, Edi Dwi Cahyono ${ }^{2}$ \\ ${ }^{1}$ Post Graduate Program in Agricultural Sociology, Faculty of Agriculture, Brawijaya University, \\ ${ }^{2}$ Department of Social Economics, Faculty of Agriculture, Brawijaya University, Jl. Veteran, Malang, \\ 65145, Indonesia
}

Received: 10 May 2017; Revised: 4 July 2017; Accepted: 31 July 2017

\begin{abstract}
Mount Kelud erupted on February 13, 2014 causing severe damage to public and private facilities in 8 villages in Ngantang, a district in Malang. Post-eruption, the social system was severely damaged, while the local society attempted to survive the disaster. This study aimed to analyze the role of communication in disaster management assisted by the existence of social capital in the aspect of cultivation of crops and agricultural infrastructure. The method used was descriptive qualitative supported by scoring data. Thfindings revealed that the role of communication was to bridge the gap in every aspect of social capital. Besides that, communication functioned as a liaison from every aspect of social capital that was used as disaster management during Mount Kelud eruption The type of communication used was interpersonal communication, where members shared activities and information face-to-face or face-to-face activities on disaster management in Mount Kelud.
\end{abstract}

Keywords: social capital; disaster management; communication

\section{How to cite:}

Inggrida, J. A., Sukesi, K., \& Cahyono, E. D. (2017). The Role of Communication in Mount Kelud Eruption Disaster Management Program ( Case Study in Ngantru Village , Ngantang District , Malang ). HABITAT, 28(2), 46-53. https://doi.org/10.21776/ub.habitat.2017.028.2.7

\section{Introduction}

Indonesia has 129 active volcanoes and 70 of them are very active causing threats for people living around them. On February 13, 2014, Mount Kelud erupted. The eruption caused mild to severe damage to the farms around the volcano. Ngantru is one of the 8 villages affected by the eruption of Mount Kelud. Losing both material and non-material possession caused some stress for the local society. Stress is defined as a state of tension that can affect emotions or thinking process of a person; too much stress decreases individual's ability to deal with the environment (Handoko, 1997). Disaster management process has been regulated in the 2007 Minister of Agriculture Regulation number 50 of 2007 on Guidelines for Disaster Prevention in Agriculture Sector. Based on the regulation, there are 4 stages of disaster management, namely rehabilitation, reconstruction, funding and management of disaster relief resources.

${ }^{*}$ Corresponding Author.

E-mail: jedda1891@gmail.com
Every stage involves stakeholders from local government to village counselor.

Social system was disturbed after the eruption. Despite of the condition, the local society was forced to survive and meet their daily need. Trust and social norm are the bases for the society to help one another. These two are the foundation of establishment of social mode in which social mode is defined as relationship that facilitates interaction between individuals and groups within the society in order to increase public welfare (Iyers, 2005).

Fukuyama (1999) stated that social mode plays pivotal role to strengthen function of the society; strong social mode helps increasing public welfare, encouraging people to work together and so forth. Social mode has positive impact as self-reinforcing. Collective action victims do to minimize damage caused by natural disaster is able to motivate the victims to remain strong and survive the disaster (Verayanti, 2013).

Woolcock (2000) stated there are 3 aspects of social mode, namely bonding (relationship between individual and his/her group), bridging (relationship between individual and another 
group), and linking (relationship between stratum in one group). Hawkins (2009) stated that social mode consisting of bonding, bridging and linking has been used frequently to survive post- disaster. Social mode is utilized during relocation and redevelopment of lives and community of disaster victim. Social mode is vital to connect and bridge bond within each community or individual, in which it is essential for post-disaster survival.

Social mode accelerates disaster prevention process. However, such process will not be effective without communication connecting each aspect of social mode. Communication connects not only all aspects of social mode but also members of the same farming groups, members of different farming groups or different stratum within farming group. Budi (2012) explained that disaster is part of humanitary operation, while determinant factor has to be developed and applied. Communication is vital during disaster because it involves participation, integration and synergy from various institution/ social groups. Therefore, communication is important during and posteruption.

The purpose of communication is to share knowledge, information, experience and message from a party to another. Communication makes it easier for individual to understand other people's attitude or feeling (Efendy, 2003) and information related to eruption will be more accessible. Farmers communicate between one another to get information about agricultural facilities/ infrastructure and cultivation. Communication may determine whether or not the government succeeds in sharing information about disaster prevention or methods to survive during natural disaster. Optimizing integrated communication is the key in disaster management, in which synergy between utilization of media and disaster victim to distribute or spread information is a must (Asteria, 2016).

Social mode has become subject of previous studies but very few discussed social mode related to agriculture. One of the previous studies discussing the relationship between social mode and natural disaster is conducted by Handayani (2012). It discusses social mode in disaster risk. The findings state that social mode is a tool for disaster management through social group as participation of the social group is essential and effective in mitigation and disaster relief. In disaster relief supported by social mode, the role of communication is important because it connects each activity related to disaster relief.

Wardyaningrum (2016) identifying social mode in communication for preparedness against natural disaster mentioned that communication is used in social mode for preparednesss against disaster phase by relying on flow of information, decision-making, and credibility of volunteer to the victim. Another study discussing communication and natural disaster is one conducted by Lestari, et.al (2012) that communication is strategy for disaster management with coordination and communication between parties related to the natural disaster; it minimizes risk caused by natural disaster.

Ngantru village in Malang Municipality is selected as the setting of the study since the village was damaged by the eruption of Mount Kelud in 2014. Syiko (2014) stated that posteruption, the status of Ngantang village changed from low to high-risk. Other high-risk areas are Pandansari, Ngantru and Pagersari villages.

Based on the previous studies, it is concluded that social mode may aid disaster management by optimizing trust and social norm since communication bridges all aspects of the disaster management. Without communication, it is getting more difficult to channel the social mode aspects towards individual, group or the society. Trust and social norm develop social mode, whereas trust and social norm may be developed due to intense communication between various actors or stakeholders. The objectives of the study are 1) analyze social mode of farming group in preventing Mount Kelud eruption in agricultural sector and 2) analyze communication of the farming groups during disaster management of Mount Kelud eruption.

\section{Methodoology}

\subsection{Data Collection Method}

The data were primary data obtained by interviewing the informants using interview guide as medium and direct observation towards the informants' behavior. The observation was conducted when they had meeting. The objective was to describe type of comminaction and interaction taking place in the meeting.

\subsection{Data Analysis Method}

Related to the objectives of the study, the data analysis methods were descriptive qualitative and scoring. The following section 
discussed the data analysis method used in the study.

\section{a. Descriptive Qualitative}

Descriptive study has 4 methods; one of them is case study of which purpose is describing natural events in the society (Wiyarti and Mulya, 2007). The case being observed in this context was Mount Kelud eruption causing damage for farmers. There was a gap between the disaster management guideline stated in the Minister's regulation and the reality. Social mode was means of survival in which communication becomes the medium.

\section{b. Scoring}

Scoring was conducted to measure 3 aspects of the social mode, bonding, bridging, and linking of production and cultivation. Likert scale was used for scoring. The procedure was as follow:

1) Stratification

The population was divided into three, high (score 3), moderate (score 2) and low (score $1)$.

2) Ratio

Ratio refers to gap between the highest observation score and the lowest one. The following formula was used to obtain $\mathrm{R}$ (ratio).

Description

$$
R=X_{t}-X_{r}
$$

R : Ratio

$\mathrm{X}_{\mathrm{t}} \quad$ : Highest Observation Score

$\mathrm{X}_{\mathrm{r}} \quad$ : Lowest Observation Score

3) Class Interval

Class interval refers to interval between the strata. The following formula was used to determine the class interval.

Description

$$
I=R / k
$$

$\begin{array}{ll}\mathrm{I} & \text { : Class Interval } \\ \mathrm{R} & \text { : Ratio } \\ \mathrm{k} & : \text { Strata }\end{array}$

\section{Findings and Discussions}

\subsection{Social Mode in Mount Kelud Eruption Disaster Management for Agriculture}

\subsubsection{Bonding in Means of Production}

Bonding refers to relationship/ interaction between individuals within the same group. Bonding has several aspects, decision-making, togetherness, trust and solidarity.
Relationship or interaction between members of Gemah Ripah 2 farmer group was really good, in which the interaction had been developed prior to eruption and improved posteruption. Decision-making represented by some freedom in giving opinion about what the farmers needed and being satisfied about the decision being taken.

Table 1. Bonding in Means of Production

\begin{tabular}{clccc}
\hline No. & $\begin{array}{c}\text { Means of } \\
\text { Producti } \\
\text { on } \\
\text { Indicator }\end{array}$ & $\begin{array}{c}\text { Observ } \\
\text { ation } \\
\text { Score }\end{array}$ & $\begin{array}{c}\text { Max. } \\
\text { Score }\end{array}$ & Category \\
\hline 1. & Seeds & 116 & 120 & High \\
2. & Fertilizer & 107 & 120 & High \\
3. & Pesticide & 107 & 120 & High \\
4. & $\begin{array}{l}\text { Water } \\
\text { Source }\end{array}$ & 114 & 120 & High \\
\hline \multicolumn{2}{c}{ Average } & $\mathbf{1 1 1}$ & $\mathbf{1 2 0}$ & High \\
\hline \multicolumn{2}{c}{ Togetherness } & was & represented in
\end{tabular}

cooperative work during election and joined effort to get better means of production. The aspect of social mode was categorized as very good. The farmers preferred working together because it saved significant amount of output and money.

Trust level between the members was high; they knew each other well and there was frequent interaction among the farmers. Trust was one of keys for the groups in carrying out disaster management program more particlarly one related to means of production.

Solidarity was developed from mutual help and sharing the means of production. The farmers feel that they experienced the same challenge and needed the same equipment

\subsubsection{Bonding in Cultivation}

Bonding refers to relationship/ interaction between individuals within the same group. Cultivation has 4 aspects, land processing, crop rotation, harvesting and marketing.

Table 2. Bonding in Cultivation

\begin{tabular}{clccc}
\hline No. & $\begin{array}{l}\text { Means of } \\
\text { Production } \\
\text { Indicator }\end{array}$ & $\begin{array}{c}\text { Observ } \\
\text { ation } \\
\text { Score }\end{array}$ & $\begin{array}{c}\text { Max. } \\
\text { Score }\end{array}$ & Category \\
\hline 1. & $\begin{array}{l}\text { Land } \\
\text { Processing }\end{array}$ & 106 & 120 & High \\
& $\begin{array}{l}\text { Crop } \\
\text { 2. }\end{array}$ & 104 & 120 & High \\
Rotation & Harvesting & 106 & 120 & High \\
4. & Marketing & 106 & 120 & High \\
\hline & Average & $\mathbf{1 0 6}$ & $\mathbf{1 2 0}$ & High \\
\hline
\end{tabular}


The group members had very strong bonding for cultivation. Relationship or interaction between members of Gemah Ripah 2 farmer group had been developed prior to eruption and improved post-eruption. Decisionmaking refered to freedom of giving opinion related to cultivation as well as decision being taken and agreed upon all group members.

Togetherness was represented in cooperative work for cultivation. The farmers preferred working together because it saved significant amount of time and money. The farmers were aware of the benefit of working together.

There are two types of trust, trust for group an individual belongs to and trust between members of the same group. Solidarity was developed from mutual help and sharing information related to cultivation. Hiring fellow farmers was also an example of solidarity among Gemah Ripah 2 farmer group members. Sharing information is an instance of solidarity in bonding aspect.

\subsubsection{Bridging in Means of Production}

Bridging refers to interaction/ relationship between members of certain group and another group. It has two aspects, interaction and cooperation.

High category the aspect had meant Gemah Ripah 2 farmer group members had good relationship with members of other farmer groups. Prior to the eruption, Gemah Ripah 2 farmer group members rarely interacted with other farmer groups in Ngantru village. It happened because different farmer groups had different programs. After the eruption, all farmers work together focusing on restoring the farm and plantation as one part of the disaster relief programs of which purpose was to provide equipment for production.

Table 3. Bridging in Means of Production

\begin{tabular}{|c|c|c|c|c|}
\hline No. & $\begin{array}{c}\text { Means of } \\
\text { Producti } \\
\text { on } \\
\text { Indicator }\end{array}$ & $\begin{array}{c}\text { Observ } \\
\text { ation } \\
\text { Score }\end{array}$ & $\begin{array}{l}\text { Max. } \\
\text { Score }\end{array}$ & Category \\
\hline 1. & Seeds & 93 & 120 & Moderate \\
\hline 2. & Fertilizer & 106 & 120 & High \\
\hline 3. & Pesticide & 93 & 120 & Moderate \\
\hline 4. & $\begin{array}{l}\text { Water } \\
\text { Source }\end{array}$ & 106 & 120 & High \\
\hline \multicolumn{2}{|c|}{ Average } & 100 & 120 & High \\
\hline
\end{tabular}

Briging for means of production had two aspects, farmer's interaction and cooperation. Farmer's interaction had a variable, communication between farmers and other groups about means of production they needed. Communication occurred not only between members of the same farmer groups (Gemah Ripah) but also between those from different farmer groups. Post-eruption, communication was essential to obtain information related to means of production the farmers needed.

There was competition among farmers. Despite of the competition, the farmers kept sharing information because they were facing the same difficulties. The second aspect was cooperative work among the farmers. Copperative work referred to helping each other to get the means of production needed. Bridging had wider context as the farmers worked together with other farmer groups to get the means of production they needed.

\subsubsection{Bridging in Cultivation}

Bridging refers to interaction/ relationship between members of certain group and another group. It has three aspects, interaction, competition and cooperation.

Table 4. Bridging in Cultivation

\begin{tabular}{clccc}
\hline No. & $\begin{array}{l}\text { Means of } \\
\text { Production } \\
\text { Indicator }\end{array}$ & $\begin{array}{c}\text { Observ } \\
\text { ation } \\
\text { Score }\end{array}$ & $\begin{array}{c}\text { Max. } \\
\text { Score }\end{array}$ & Category \\
\hline 1. & $\begin{array}{l}\text { Land } \\
\text { Processing }\end{array}$ & 105 & 120 & High \\
2. & $\begin{array}{l}\text { Crop } \\
\text { Rotation }\end{array}$ & 105 & 120 & High \\
3. & Harvesting & 106 & 120 & High \\
4. & Marketing & 105 & 120 & High \\
\hline & Average & $\mathbf{1 0 5}$ & $\mathbf{1 2 0}$ & High \\
\hline
\end{tabular}

The members of Gemah Ripah 2 farmer group had good interaction with members of other farmer groups. Interaction referred to share and exchange of information among farmers from different farmer groups. The information was related to cultivation. Prior to the eruption, each farmer group had different focus and there was not any competition among the groups. Posteruption, competition started happening because the farmers had exactly the same need. The farmers considered the competition as normal phenomenon since it did not lead to any argument. Even though competition has negative connotation, the competition taking place strengthened the relationship between the 
farmers, more particularly after eruption, because they were facing the same difficulty.

Besides the competition, the farmers helped each other by hiring farmers. The farmers who needed some help with their farm land may hire other farmers. The farmers were allowed to hire other farmers from other farmer groups. The purpose was to accelerate revitalization of farm land/ plantation in Ngantru village.

\subsubsection{Linking in Means of Production}

Linking refers to relationship/ interaction between different strata. Linking has two aspects, access to information and use of media to access information.

Table 5. Linking in Means of Production

\begin{tabular}{clccc}
\hline No. & $\begin{array}{c}\text { Means of } \\
\text { Producti } \\
\text { on } \\
\text { Indicator }\end{array}$ & $\begin{array}{c}\text { Observ } \\
\text { ation } \\
\text { Score }\end{array}$ & $\begin{array}{c}\text { Max. } \\
\text { Score }\end{array}$ & Category \\
\hline 1. & Seeds & 92 & 120 & Average \\
2. & Fertilizer & 92 & 120 & Average \\
3. & Pesticide & 94 & 120 & High \\
4. & Water & 119 & 120 & High \\
\hline & Source & & & \\
\hline \multicolumn{2}{l}{ Average } & $\mathbf{9 9}$ & $\mathbf{1 2 0}$ & High \\
\hline
\end{tabular}

Relationship or interaction between strata in Gemah Ripah 2 farmer group in terms of spreading information was very good. The higher stratum was source of information and the lower one was recipient. Post-eruption, there was unclear division on who the source and the recipient were.

Linking has 3 aspects; the first is use of audio visua media or TV to obtain information about fertilizer and pesticide. Audio visual media were one of the primary needs of the farmers. They watched TV to increase knowledge and gain information about means of production, fertilizer and pesticide.

The second is access to information. Information came from different sources having different strata, such as farmers from the same farmer group, public counselor, private counselor, and government staffs. Coming from different strata, the sources of information had indirect relationship between each other.

\subsubsection{Linking in Cultivation}

Linking refers to relationship/ interaction between different strata. Linking has two aspects, access to information and use of media to access information about cultivation consisting of land processing, crop rotation, harvesting and marketing.

Relationship or interaction between strata in Gemah Ripah 2 farmer group in terms of spreading information was very good. As mentioned previously, there was unclear division on who the source and the recipient were after the eruption. Communication referred to interpersonal communication between two people.

Table 6. Linking in Cultivation

\begin{tabular}{clccc}
\hline No. & $\begin{array}{l}\text { Means of } \\
\text { Production } \\
\text { Indicator }\end{array}$ & $\begin{array}{c}\text { Observ } \\
\text { ation } \\
\text { Score }\end{array}$ & $\begin{array}{c}\text { Max. } \\
\text { Score }\end{array}$ & Category \\
\hline 1. & $\begin{array}{l}\text { Land } \\
\text { Processing }\end{array}$ & 107 & 120 & High \\
2. & $\begin{array}{l}\text { Crop } \\
\text { Rotation }\end{array}$ & 106 & 120 & High \\
3. & Harvesting & 107 & 120 & High \\
4. & Marketing & 108 & 120 & High \\
\hline & Average & $\mathbf{1 0 7}$ & $\mathbf{1 2 0}$ & High \\
\hline
\end{tabular}

Linking as social mode connected different strata so that people were able to spread and exchange information about cultivation. Linking had to aspects, access to information and use of audio-visual media to access information.

The use of the audio-visual media was watching TV to increase knowledge and gain information about cultivation after Mount Kelud eruption. TV enables the farmers to get more varied and trustworthy information. In other words, TV was the source of information and the farmers were the recipient.

Access to information was pivotal for the farmers especially after the eruption. After the eruption, the farmers actively searched for information without any help more particulary one they could not get from the sources of information.

\subsection{Communication in Mount Kelud Eruption Disaster Management Program for Agriculture \\ Communication, connecting social mode,} is foundation in accelerating disaster management process after the eruption. Social mode was the farmers' means for survival when their social system was severely damaged. Social mode has several aspects connected by communication. Communication connects members within the same group or farmers from different farmer groups. Communication spreads 
information, mediates one-on-one interaction, trust and solidarity.

\subsubsection{Communication in Bonding}

In bonding, the type of communication taking place was interpersonal communication between two members of Gemah Ripah 2 group members. The members communicated to each other because they trusted one another; the more frequent their interaction was, the higher the trust level was. Trust may increase level of participation, for example the farmer group members' participation in decision-making related to means of production and cultivation.Trust enabled them to state their opinion and share information more easily. It developed cohesiveness and solidarity between members.

Communication occurred during or outside the group meeting. After the eruption, the communication/ interaction was getting more intensive because the farmers needed a lot of information related to disaster relief. Those getting involved in interpersonal communication had the same roles since any of them may become the source of information and recipient. Not only did communication allow spread or exchange of information, but it also strengthened the bond Gemah Ripah 2 farmer group members had.

\subsubsection{Communication in Bridging}

Interpersonal communication also took place in bridging. What distinguished it was Gemah Ripah 2 farmer group members interacted with the members of Gemah Ripah 1 and 3 farmer groups. Before the eruption, this type of communication rarely happened due to different programs these groups had. After the eruption, these groups communicated more intensively in order to avoid overlapping of information.

Communication improved the interaction these farmers had. Their interaction also became more frequent. Frequent interaction resulted in cooperation between the farmer groups. As the effect of the interaction, Gemah Ripah 2 group members were able to get information they needed from other groups. Differences these groups had previously disappeared because they had the same need after the eruption of Mount Kelud. These interactions also resulted in some competition more particularly some sort of competition to get information about marketing. The competition did not lead to any argument or conflict because these farmers overcame any differences they had immediately.
As an addition, effective communication also facilitated problem-solving. Leader of the farmer group or center became mediator to solve the issues the farmers had. It minimized problem stemmed from differences the farmers group had.

\subsubsection{Communication in Linking}

Type of communication during linking was interpersonal communication between two people. However, this time, the ones getting involved were Gemah Ripah 2 farmer group members from different strata. Basically, the members from higher stratum became the source of information or message while the ones with the lower stratum became the recipient. After the eruption of Mount Kelud, such stratification changed because the members having the lower stratum may be the source of information and the ones with the higher stratum became the recipient. Communication was useful for obtaining information related to production facilities and cultivation. Access to information, especially one with clear and straightforward message, became an important factor in communication.

Clear and valid information helped both the recipient and other farmers in interpersonal communication. Interpersonal communication may be face-to-face interaction or facilitated by a medium such as cellular phone. Farmers spread information they got from the wholesaler to other farmers from the same or different farmer groups. In this case, the farmers became both the recipient and later the source of message or information.

Besides other farmers and wholesaler, another source of information was television. Before the eruption, the locals did not watch TV to get information about agriculture. After the eruption, they watched TV to get information on both agricultural and non-agricultural sector. The role of television was complementary in interpersonal communication.

\section{Conclusion}

Mount Kelud eruption disaster management program in agriculture may be conducted by providing means of production and cultivation. Cooperation, not only one between farmers but also between farmers group, is the key for successful and effective implementation of such program. Good communication enables the farmers to state their opinion and information they get to other farmers. There are various sources of information such as fellow farmers, 
counselor, members of different farmer groups, wholesaler, or television.

Social mode and communication are closely related. Social mode is the means for survival after the eruption while communication mediates interaction between a farmer and his/her farmer group as well as a farmer with other farmer groups. Neither disaster management nor communication works well without communication. Interpersonal communication is type of communication used to spread and exchange information.

After the eruption, source of information send messages within communication process. Source of information refers to individual having sufficient knowledge such as government staff, public and private counselors. They send information related to means of production and farmers are the recipient. Even though they are several stratum classified based on experience and social status, after the eruption of Mount Kelud, individual may switch roles; source of information may become recipient and viceversa. Information from one farmer to another in the same farmer group does not have clear process or pattern of communication. Neither source of information nor recipient has exact, fixed role. It happens since farmers can change role depending on the information he or she has. A farmer who once became the source of information may become a recipient and viceversa.

\section{References}

Asteria, Donna. 2016. Optimalisasi Komunikasi Bencana di Media Massa Sebagai Pendukung Manajemen Bencana. Jurnal Komunikasi 01, Ikatan Sarjana Komunikasi Indonesia, pp.1-11.

Budi, Setio. 2012. Komunikasi Bencana : Aspek Sistem (Koordinasi, Informasi dan Kerjasama). Jurnal Komunikasi, Volume 1, Number 4, pp.363-372.

Efendy, Onong Uchjana. 2003. Ilmu Komunikasi : Teori dan Praktek. PT Citra Aditya Bakti. Bandung.

Fukuyama, Francis. 1999. Social Capital and Civil Society. The Institute of Public Policy. George Mason University.

Handayani, Baiq Lily. 2012. Jaringan Kelompok Perempuan Sebagai Modal Sosial Yang Potensial Dalam Manajemen Resiko
Bencana Berbasis Masyarakat Di Desa Kemiri Kecamatan Panti Kabupaten Jember. Master's Degree in Sociology, Faculty of Social and Political Science, Airlangga University. Surabaya.

Handoko, T. Hani. 1997. Manajemen dan Sumber Daya Manusia. Liberty. Yogyakarta.

Hawkins, Robert L and Katherine Maurer. 2009. Bonding, Bridging and Linking: How Social Capital Operated in New Orleans following Hurricane Katrina. Published by Oxford University Press on behalf of The British Association of Social Workers (British Journal of Social Work, 2010 40), page 1777-1793.

Iyers and Weeks, M. 2005. Social Interactions, Reproductive Externalities and Fertility Behaviour in Kenya Mimeo. Faculty of Economics, Cambridge University. Cambridge.

Lestari, Puji, dkk. 2012. Manajemen Komunikasi Bencana Merapi 2010 Pada Saat Tanggap Darurat. Jurnal Ilmu Komunikasi, volume 10 number 2, pp.173-197.

Ministry of Agriculture. 2007. Peraturan Menteri Pertanian Nomor 50/Permentan/OT.140/6, the 2007 Minister of Agriculture Regulation about Guideline for Disaster Management in Agricultural Sector.

Syiko, Sitti Febriyani; Turniningtyas Ayu Rachmawati; Arief Rachmansyah. 2014. Analisis Resiko Bencana Sebelum dan Setelah Letusan Gunung Kelud Tahun 2014 (Studi kasus di Kecamatan Ngantang, Malang).J-PAL, Vol. 5, No. 2, 2014 ISSN: 2087-3522 E-ISSN: 2338-1671.

Verayanti, Lany. 2013. Pemanfaatan Modal Sosial Sebagai Strategi Masyarakat dalam Mengatasi Dampak dan Upaya Menurunkan Tingkat Resiko Bencana: Studi Kasus: Nagari Batu kalang Kecamatan Padang Sago Kabupaten Padang Pariaman Provinsi Sumatera Barat. Article Graduate Program in Sociology, Andalas University, Padang, pp.1-18.

Wardyaningrum, Damayanti. 2016. Modal Sosial Inklusif Dalam Jaringan Komunikasi Bencana. Jurnal ASPIKOM, Volume 3 Number 1, pp.33- 55 . 
Wiyarti, Sri dan Sutapa Mulya. 2007. Sosiologi. UNS Press. Surakarta.

Woolcock, M. D. Narayan. 2000. Social Capital: Implication for Development Theory, Research, and Policy. World Bank Research Observer, 15(2), August, 225-49. In Elinor Ostrom and T.K. Ahn. 2003. Foundation of Social Capital. Massachusetts: Edward Elgar Publishing Limited. 